\title{
Responses of ring widths and maximum densities of Larix gmelinii to climate on contrasting north- and south-facing slopes in central Siberia
}

Joni Kujansuu, Koh Yasue, Takayoshi Koike, Anatoly P. Abaimov, Takuya Kajimoto, Takashi Takeda, Morihiko Tokumoto, Yojiro Matsuura

J. Kujansuu. United Graduate School of Agricultural Science, Gifu University, Gifu 501-1193, Japan

J. Kujansuu, K. Yasue ${ }^{1}$, T. Takeda, and M. Tokumoto. Department of Forest Science, Faculty of Agriculture, Shinshu University, 8304 Minami-Minowa, Nagano 399-4598, Japan

T. Koike. Field Science Center for the Northern Biosphere, Hokkaido University, Sapporo 060-0811, Japan

A.P. Abaimov. Sukachev Institute of Forest, Siberian Branch, Russian Academy of Science, Academgorodok, Krasnoyarsk 660036, Russia

T. Kajimoto. Kyushu Research Center, Forestry and Forest Products Research Institute, Kumamoto 860-0862, Japan

Y. Matsuura. Forestry and Forest Products Research Institute, Tsukuba 305-8687, Japan

${ }^{1}$ Corresponding author: e-mail:yasue@shinshu-u.ac.jp; $\quad$ Tel.+81-265-77-1510; $\quad$ Fax. $+81-265-72-5259$ 


\begin{abstract}
An analysis was performed of the climatic responses of the radial growth of Larix gmelinii (Rupr.) Rupr. at two sites, both of which included contrasting north- and south-facing slopes, in Tura, central Siberia, with the development of ring width and maximum-density chronologies for each slope. Both residual and standard chronologies of ring widths were positively correlated with temperature from late May until mid June on all four slopes. By contrast, standard chronologies of ring widths were negatively correlated with precipitation during the winter (from October to April) and in May on the north-facing slope at site one and on the south-facing slope at site two, respectively. The negative correlations with precipitation during the winter and in May on some of the slopes suggested that delayed snowmelt in early spring might inhibit the radial growth of L. gmelinii, and the effects of snow are likely to vary with topography. Both residual and standard chronologies of maximum densities were positively correlated with temperature in early July on all four slopes. Maximum densities were also positively correlated with precipitation during summer of the previous year on all the slopes. These suggest that no major differences exist in terms of responses of maximum density to climatic factors between the north- and south-facing slopes.
\end{abstract}

Key words: Larix gmelinii, Siberia, climatic response, ring width, maximum density 


\section{Introduction}

The response of vegetation in the boreal forests of the Northern Hemisphere might have a significant feedback effect on the global climate because plants act as a sink for $\mathrm{CO}_{2}$. The vegetation on much of the Eurasian continent is dominated by Larix species (Abaimov et al. 1997). Thus, responses of Siberian larch forests to climate change might be expected to have a significant effect on carbon fixation. With respect to future changes in climate, increases in temperature appear to be among the most important factors that will affect the growth of trees in the northern boreal forests (Stewart et al. 1998). Significant correlations between spring temperatures and the tree-ring widths of conifers (Vaganov et al. 1999) and Larix species (L. sibirica Ledeb., L. gmelinii and L. cajanderi Mayr.) (Kirdjanov and Zaharjevsky 1996; Naurzbaev and Vaganov 2000; Kirdyanov et al. 2003) have been demonstrated at various locations in Siberian boreal forests. The significant effects of estimated timing of snowmelt on tree-ring widths in the Siberian Taiga have also been reported (Vaganov et al. 1999; Kirdyanov et al. 2003).

Differences in topographical features, such as slope exposure, may cause differences in growth (Koike et al. 1998; Kirchhefer 2000). In our previous study, we compared climatic responses of ring width of L. gmelinii growing on both upper and lower part of contrasting north- and south-facing slopes (total of four plots) in Tura, central Siberia (Kujansuu et al. in press). We found that 1 ) temperature from the end of May until the early June significantly correlated with ring widths at all the plots, 2) standard chronologies of ring widths on the north-facing slope were negatively correlated with precipitation during the winter (October-April) and in early and mid May, and 3) there was little difference in climatic responses between upper and lower parts of the slopes. The difference in responses to precipitation between the slopes indicated that the effects of precipitation may vary with micro-scale topography (Kujansuu et al. in press). However, the research was conducted in only a single site so the results remained to be confirmed at other sites.

Tree-ring density is also important as a tree-ring parameter in efforts to estimate the amount of carbon stored in tree trunks. There have been reported significant correlations between maximum density of tree rings and summer temperature (Briffa et al. 1995; Kirdjanov and Zaharjevsky 1996; Kirdyanov et al. 
2003). Because of their sensitiveness to summer temperature, maximum densities were used for past climate reconstructions (Briffa et al. 1995, 2001). However, to our knowledge the influence of site conditions, such as slope exposure, active soil layer depth, etc., on the responses of ring density to climate has not been reported.

This study was designed to 1) confirm the responses of ring widths to temperature and precipitation in north- and south-facing slopes at another site, and 2) investigate the climatic responses of maximum densities of larch trees growing in contrasting north- and south-facing slopes. A comparison of the climatic responses under various growth conditions will help us to understand the mechanisms that control the radial growth of L. gmelinii growing in Siberian permafrost.

Materials and methods

Study sites and sample trees

The study area is located in the Tura Experiment Forest (64ำ $19^{\prime} \mathrm{N}, 100^{\circ} 13^{\prime} \mathrm{E} ; 200 \mathrm{~m}$ a.s.l.) of the Sukachev Institute of Forest (Siberian Branch, Russian Academy of Science, Russia), on the Central Siberian Plateau, close to the western edge of a region of continuous permafrost (Fig. 1). The climate of the region is continental, with very cold winters and relatively warm summers. The mean annual temperature is $-7.6^{\circ} \mathrm{C}$, as determined at the Tura Meteorological Station (Russian Research Institute of Hydrometeorological Information - World Data Center, RIHMI-WDC; http://www.meteo.ru/data/emdata.htm). The mean temperature in January is $-36.5{ }^{\circ} \mathrm{C}$ and that in July is $17.3^{\circ} \mathrm{C}$. The mean annual precipitation is $380 \mathrm{~mm}$.

We chose two sites that included contrasting north- and south-facing slopes (Fig. 2). Site one, which was reported in our previous study (Kujansuu et al. in press), was located in a small valley on a tributary of Kochechum River (Fig. 1). The difference in elevation between the riverbed and the hilltop is approximately $30 \mathrm{~m}$, and the gradient of the slope is $18^{\circ}$ on the south-facing slope and varies between $8^{\circ}$ and $18^{\circ}$ on the north-facing slope. Site two is located about $30 \mathrm{~km}$ to the east of site one, on the gentle hill located about $3 \mathrm{~km}$ south from the Nizhnaya Tunguska River (Fig. 1). The difference in elevation between the plots and the hilltop is approximately $9 \mathrm{~m}$, and the gradients of the slopes are much less steep, being $5^{\circ}$ on both the north- and the south-facing slope. Site one and site two are almost entirely dominated by L. gmelinii. 
The forest at site one became established after a forest fire that occurred in the early 1800's, whereas the forest at site two became established after a forest fire that occurred approximately 100 years ago. Forest stand on the north-facing slope of site one is uneven-aged, caused by survivors of the forest fire, whereas the south-facing slope is even-aged. Both plots in site two are evenaged. The depth of the active soil layer differed markedly between the north- and south-facing slopes at each site (Fig. 2). The depth of the active soil layer at site one was $148 \mathrm{~cm}$ on the south-facing slope and only $45 \mathrm{~cm}$ on the north-facing slope in the summer of 1997 (Koike et al. 1998). The depth of the active soil layer at site two was $175 \mathrm{~cm}$ on the south-facing slope and 63 cm on the north-facing slope in the autumn of 2003.

At site one, we chose two plots (approximately 40 x $40 \mathrm{~m}$ ) in upper and lower part of each slope reported in our previous reports (Kujansuu et al. in press), and combined the samples from the both plots altogether per plot because there was little difference in chronology statistics and climatic responses within a slope. We established one plot of $10 \times 15$ m per slope at site two. The plot names are designated in the text as $1 \mathrm{~N}$ and $1 \mathrm{~S}$ for north- and south-facing slopes on site one and $2 \mathrm{~N}$ and $2 \mathrm{~S}$ for site two. We examined a total of sixty dominant trees per plot at site one and thirty dominant trees per plot at site two (Table 1).

\section{Development of chronologies}

We utilized the ring-width data used in the previous study at site one. The extracted incremental cores were also utilized for density measurement. At site two, we cut disk samples at a height of $30 \mathrm{~cm}$ from the ground in the spring of 2004 to obtain good-quality X-ray photos. Two strips cut from opposite directions were prepared per tree. We performed hot-water extraction for 4 days and ethanol extraction for 6 days to eliminate resin and heartwood substances. After extraction, all samples were cut into 1.55-mm-thick strips with a twin-blade saw. The strips were dried to moisture content of $12 \%$ in conditioned air at $20{ }^{\circ} \mathrm{C}$ and $65 \%$ humidity and were subjected to $\mathrm{X}$-ray analysis (Softex EMBW, Softex Co., Ebina, Japan; working distance 2.2 m, 20 kVp, $14 \mathrm{~mA}, 3 \mathrm{~min} 30 \mathrm{sec}$ ) in combination with a calibration wedge. The radiograms were scanned at a resolution of 3,200 dpi with a scanner (GT-X700; Epson, Suwa, Japan). The resolution of captured images was $7.9 \mu \mathrm{m} /$ pixel. The images were analyzed for the 
determination of ring widths and maximum ring densities with the WinDENDRO program (Density 2003b, Regent Instruments Inc., Quebec, Canada). The tree-ring widths of core samples from site one were measured to a precision of $0.01 \mathrm{~mm}$ under a stereomicroscope (MZ6; Leica, Solms, Germany) that was equipped with a system for tree-ring measurements from Velmex Inc. (Bloomfield, NY, USA; Kujansuu et al. in press).

The series of tree-ring widths and maximum densities were cross-dated visually by using skeleton plot procedures and confirmed by a statistical method to ensure that the correct date had been assigned to each annual ring (Stokes and Smiley 1996). Statistical cross-dating was performed with the COFECHA program (Holmes 1983, 1994) that tests each individual series against a master dating series (mean of all series) based on correlation coefficients. During the cross-dating, samples in which there was evidence of the extensive formation of reaction wood were excluded. In the measurement series of maximum density at sites one and two and of ring width at site two, we excluded the samples due to the poor quality of radiograms. This was caused by the oblique angle of fibers to X-ray irradiation. We also excluded juvenile period (approximately 15 years from the beginning of the series) that exhibited ring width variations that un-synchronized among trees and increasing trend in maximum density.

The series of measurements of ring widths and maximum densities were standardized by fitting smoothing splines (Cook and Peters 1981), with a 50\% frequency-response cutoff of 80 years, for the extraction of climatic signals. The cut-off length was chosen because of the highest correlations between trees of standardized series among those obtained fitting other curves including negative exponential. Autoregressive modeling was used to remove the effect of autocorrelation from the standard series. Standardization and autoregressive modeling were performed with the ARSTAN program (Cook 1985) that produces chronologies from tree-ring measurement series by detrending and standardizing the series. The standard and residual chronologies of ring widths and maximum densities for each plot were developed by averaging the individual series by using a biweight robust mean to weaken the endogenous disturbance effects and other sources of noise. Expressed population signal (EPS) analysis (Wigley et al. 1984; Briffa and Jones 1990) was used to assess the degree to which chronologies of each plot portraits the hypothetical 
perfect chronology.

Responses to climatic variables

We analyzed the responses of ring widths and maximum densities to climatic variables by calculating simple correlations with both residual and standard chronologies. Residual chronologies were used because of elimination of autocorrelation that negates the assumption of the independence that is necessary for most statistical analyses (Fritts 1976; Monserud 1986). We also used standard chronologies to analyze the effect of low-frequency fluctuations in climate that were eliminated through autoregressive modeling. The climatic data used for calculations were obtained from the Tura Meteorological Station. Average daily mean temperatures for ten consecutive days were used in the analysis, with a two-day lag, starting from May 1 of the previous year. We also used the amount of monthly precipitation from May through September of the previous year and from May through August of the current year. Winter precipitation was calculated as the total precipitation from October of the previous year to April of the current year because the precipitation falls as snow. In addition, the precipitation in May of the current year was divided into precipitation during the early, middle and late parts of the month for assessment of the short-term effects of early-spring precipitation. The precipitation data of winter, May and August have high year-to-year autocorrelation $(0.45,0.21$ and -0.43 , respectively). The analysis of tree-ring parameters and temperature covered the period from 1930 to $1995(n=65)$. The analysis of tree-ring parameters and precipitation covered the period from 1939 to $1995(n=56)$.

Results and discussion

Chronology statistics

Cross-dating was performed successfully and standard and residual chronologies were developed for all four plots (Figs. 3 and 4). As shown in Table 2, first-order autocorrelations of standard chronologies of ring widths revealed stronger correlations on $1 \mathrm{~N}(0.60)$ and on $2 \mathrm{~S}(0.60)$ than those on $1 \mathrm{~S}(0.35)$ and on $2 \mathrm{~N}(0.37)$. The mean correlation between trees in the standard chronologies of tree-ring widths on $1 \mathrm{~N}(0.34)$ was lower than that on $1 \mathrm{~S}(0.48)$, whereas mean correlations on the slopes at site two (2S, $0.42 ; 2 \mathrm{~N} 0.45)$ were quite similar. The mean correlation between trees in the 
residual chronologies of tree-ring widths on $1 \mathrm{~N}(0.37)$ was lower than that on $1 \mathrm{~S}(0.52)$, whereas correlations on the slopes at site two $(2 \mathrm{~N}, 0.44$; $2 \mathrm{~S} 0.41)$ were quite similar.

First-order autocorrelations of standard chronologies of maximum densities revealed higher values at site one $(1 \mathrm{~N}, 0.56 ; 1 \mathrm{~S}, 0.40)$ as compared to site two $(2 \mathrm{~N}$, 0.35; 2S, 0.22; Table 2). The mean correlations between trees ranged between 0.30 and 0.34 on all the slopes except for $1 \mathrm{~S}$, which yielded a value of 0.38 . Mean sensitivities, standard deviations and mean correlations between trees of residual chronologies of maximum densities were similar for both sites.

The remarkable higher first-order autocorrelation of standard chronology of ring width was observed at south-facing slope of site two, in spite that was observed at north-facing slope of site one (Kujansuu et al. in press). The higher first-order autocorrelations might be attributed to predominance of low-frequency fluctuation caused by climatic factors. The cause of the differences between the two sites will be discussed with their climatic responses in following section.

\section{Climatic responses of ring widths}

Residual chronologies of ring widths on all plots responded positively to temperature from the end of May to the middle of June (Fig. 5). Residual chronologies also responded positively to temperature at late June and from the end of July to early August on all the slopes except on 2N. Residual chronologies on both slopes at site one were negatively correlated with temperatures in early March of the current growth year. Residual chronologies on $1 \mathrm{~S}$ and 2S were negatively correlated with temperatures from late March to early April of the current growth year. Residual chronologies on both slopes at site one responded negatively to temperatures from late April to early May of the current growth year. Residual chronologies on both slopes at site two responded negatively to temperatures from late December to early January of the winter preceding the current growth year. The following significant correlations with temperature were recorded only for single plots: on 1S, there was a negative response in early July of the previous year; on $2 \mathrm{~N}$, a negative response was found in October; and, on $2 \mathrm{~S}$, there were positive responses at the middle of June of the previous year and from the end of January to early February of the current growth year. The responses of standard chronologies to temperature were similar to those of residual 
chronologies with exception of revealing positive correlations with temperature of middle May of the current growth year at $1 \mathrm{~N}, 1 \mathrm{~S}$ and $2 \mathrm{~S}$, and that of the previous growth year at $1 \mathrm{~N}$ and $2 \mathrm{~S}$.

Residual chronologies of ring widths were not significantly correlated with precipitation except 1S that yielded a positive correlation with precipitation during the August of the previous year (Fig. 6). In contrast to residual chronologies, standard chronologies of ring widths on $1 \mathrm{~N}$ and $2 \mathrm{~S}$ were negatively correlated with precipitation during the winter and during the month of May of the current year. Standard chronology at $1 \mathrm{~N}$ also yielded a negative correlation with precipitation in May of the previous year.

The low-frequency variations in precipitation of winter and May, and standard chronologies were compared (Fig. 7). There was a remarkable difference in growth trend from 1960s to 1980s among the plots. Five year moving average of standard chronology of $1 \mathrm{~N}$ revealed clear decline from late 1960s to early 1970s which coincided with increasing trend in both winter and May precipitation. That of 2S revealed growth reduction from middle 1970s to middle 1980s which can be attributed to period of higher precipitation in winter. The growth trend in $1 \mathrm{~S}$ and $2 \mathrm{~N}$ did not reveal clear growth reduction in the period from 1960s to 1980s and also did not reveal synchronization with trends of precipitation of winter and May.

Our present results demonstrated that temperatures from late May to mid June of the current growing season mostly determined the ring widths in both sites one and two. It is possible that temperatures within this period influence both leaf development stages and the resultant photosynthesis that can promote cambial activity. The results are also consistent with previous reports on the temperature responses of Larix species in Siberia (Vaganov et al. 1999; Kirdyanov et al. 2003).

A negative effect of precipitation of winter and May on standard chronologies of ring widths, which already found in $1 \mathrm{~N}$ (Kujansuu et al. in press), was also observed in $2 \mathrm{~S}$. The standard chronologies at both $1 \mathrm{~N}$ and $2 \mathrm{~S}$ not only revealed significant correlations with precipitation of winter and May but also coincided with low-frequency trend in precipitation of winter and May. The remarkable higher first-order autocorrelations, that might be attributed to predominance of low-frequency fluctuations, were also observed in standard chronologies of both $1 \mathrm{~N}$ and in $2 \mathrm{~S}$ (Table 
2). These points in common indicate that precipitation of winter and May affect similarly ring widths on both $1 \mathrm{~N}$ and $2 \mathrm{~S}$ in spite of opposite slope exposure.

The precipitation of winter and May might represent snow accumulation in the beginning of growing season because the snow thawing was observed at late May in this region (Kujansuu et al. in press). Thus the accumulated snow in spring might limit the ring width in both $1 \mathrm{~N}$ and $2 \mathrm{~S}$. The significant correlations between standard chronologies of ring width and temperature of middle May observed only in standard chronologies (Fig. 5) also support the importance of snow accumulation in May on variations in ring widths. It is possible that more snow was accumulated to south-facing slope than that to north-facing slope in site two by snowdrifts.

In our previous report, we pointed out a possibility that delayed soil thawing caused by accumulated snow in spring lead to limit root activity in the north-facing slope where the soil active layer was shallow (Kujansuu et al. in press). The present results indicate that differences in responses to precipitation of winter and May can not be connected to differences in depth of active soil layer in late summer. Thus, the root activity in the early of the growing season might play an important role in variation of ring width.

Negative effect of winter precipitation on ring width has also been demonstrated in Pinus sylvestris L. over its northern range of distribution in western Siberia (Thomsen 2001). The significant effect of the timing of snowmelt, which was estimated by a model with temperature and winter precipitation, on tree-ring width in the Siberian Taiga has also been reported for conifers (Vaganov et al. 1999) and Larix species (Kirdyanov et al. 2003). The cited authors stated that the trend towards increased precipitation in winter and the delay in snowmelt in the spring might have a significant effect on the radial growth of larch trees in Siberia. However, our present results suggest that the effects of increasing precipitation depend on topographical conditions.

Climatic responses of maximum densities

The residual chronologies of maximum densities were positively correlated with temperatures during early and middle July in all four plots (Fig. 8). Those on both slopes at site one and $2 \mathrm{~S}$ also responded positively to temperature at early August. 
Residual chronologies on both slopes at site one were negatively correlated with temperatures in August of the previous year and from the end of April to early May of the current growth year. Those on both slopes at site two responded negatively to temperatures from late December to early January of the winter that preceded growth. The following significant responses of residual chronologies of maximum density to temperature were recorded only for single plots: $1 \mathrm{~N}$ yielded a positive response from the end of May to early June; 2N yielded a positive correlation in June of the previous year and for the late of June of the current year, whereas a negative response was found in October. The standard chronologies revealed quite similar responses to temperature compared with those of residual chronologies (Fig. 8).

Residual chronologies of maximum densities on all plots were positively correlated with precipitation in August of the previous year except on 1N (Fig. 9). Those on both slopes at site one were positively correlated with precipitation in July of the current year. The residual chronology on $1 \mathrm{~N}$ was negatively correlated with precipitation in May of the previous year.

Standard chronologies of maximum densities on $1 \mathrm{~N}$ revealed positive correlation with precipitation of July of the previous year and negative correlation with precipitation in May of the current year (Fig. 9). At the other plot, standard chronologies revealed significant correlations as were also the case for residual chronologies.

The results on responses to climate indicated that temperature from early to middle July and that from the end of July to early August were the most important climatic determinants of maximum density showing positive correlations. A little difference in responses to temperature was found among all plot, as was reported for ring width. The periods revealing significant correlations were about one month later than those revealed positive correlation with ring widths.

The positive responses of maximum densities to summer temperature coincided to the previous reports on Larix species in Siberia (Briffa et al. 1995; Kirdjanov and Zaharjevsky 1996; Kirdyanov et al. 2003). It is possible that the thickening of cell walls of last-formed cells, which regulate variations in maximum density (Yasue et al. 2000), is strongly influenced by the photoassimilate production during July and early August. The radial cell division of L. gmelinii growing in this 
region ceased within July (Yasue et al. 2006), thus the products of photosynthesis can serve as an abundant source of carbohydrate for the thickening of cell walls. There were also reports on positive correlation between cell wall thickness and summer temperature for L. cajanderi in north eastern Siberia (Panyushkina et al. 2003) and for L. sibirica and L. gmelinii in the northern part of central Siberia (Silkin and Kirdyanov 2003). Furthermore, Shcherbatjuk et al. (1990) demonstrated that temperatures of 14 to $16{ }^{\circ} \mathrm{C}$ are optimal for photosynthesis in L. sibirica, and these temperatures coincide with those identified as important in our present study.

The positive correlations between maximum densities and precipitation in July or August of the previous year at all plots and those in July of the current year at both slopes in site one indicate the importance of summer precipitation on maximum density. The lower precipitation in summer might cause water stress and reduced photosynthesis. The significant correlations with precipitation in the previous year suggest that stored photoassimilate is used for cell wall thickening in the following year. The negative correlations with precipitation of both previous and current May in $1 \mathrm{~N}$ indicate that spring snow accumulation can affect negatively not only ring width but also maximum density in $1 \mathrm{~N}$.

The climatic responses of maximum densities to climatic factors did not reveal major differences between south- and north facing slopes of the two sites. It has been reported for L. gmelinii seedlings in Siberian permafrost that latewood was made of photoasimilate in current July and August, and also stored material in some cases (Kagawa et al. 2006). The present results for responses of maximum density to both temperature and precipitation agrees well with the results observed by Kagawa et al. (2006).

Conclusion

Our present results confirmed that temperatures from late May to the middle June are the most important determinant of ring width of Larix gmelinii in central Siberian permafrost, regardless of site conditions such as slope exposure. The precipitation during winter and May might be an inhibitor of ring width in some growth sites. The presence of the significant responses did not depend on depth of active soil layer in late summer. It probably due to snow accumulation that may limit 
root activity in the early of the growing season.

The results also suggested that temperature of July and August of the current growing season were the most important climatic determinants of maximum density. Precipitation of July and August of both previous and/or current years also positively affect maximum density. The responses of maximum densities to climatic factors do not vary depending on local topography. 
Acknowledgements

We thank Drs. E. Vaganov and A. Kirdyanov of the Sukachev Institute of Forest for their valuable comments and useful information. We also thank Dr. O. Zyryanova, Mr. V. Borobikov and the staff of the Sukachev Institute of Forest for their help in the field sampling. We thank Dr. Takeshi Fujiwara and his colleagues of Forestry and Forest Products Research Institute for giving facilities for X-ray. This study was supported in part by funds for the "Integrated Study for Terrestrial Carbon Management of Asia in the $21^{\text {st }}$ Century Based on Scientific Advancement” from the Ministry of Environment, Japan (FY2002-2006). J. Kujansuu is grateful for a fellowship from the Japan Society for the Promotion of Science (JSPS 13701) and also acknowledges earlier support from the Finnish Cultural Foundation. 


\section{References}

Abaimov AP, Lesinski JA, Martinsson O, Milyutin LI (1997) Variability and ecology of Siberian larch species. Swedish University of Agricultural Sciences, Department of Silviculture. Report 43

Briffa K, Jones PD (1990) Basic chronology statistics and assessment. In: Cook ER, Kairiukstis LA (eds) Methods of dendochronology. Kluwer Academic Publishers, Dordrecht, the Netherlands. pp 137-152

Briffa KR, Jones PD, Schweingruber FH, Shiyatov SG, Cook ER (1995) Unusual twentieth-century summer warmth in a 1,000-year temperature record from Siberia. Nature 376:156-159

Briffa KR, Osborn TJ, Schweingruber FH, Harris IC, Jones PD, Shiyatov SG, Vaganov EA (2001) Low-frequency temperature variations from a northern tree ring density network. J Geophys Res D: 2929-2941

Cook ER (1985) A time-series analysis approach to tree ring standardization. Ph.D. dissertation, University of Arizona, Tucson

Cook ER, Peters K (1981) The smoothing spline: a new approach to standardizing forest interior tree-ring width series for dendroclimatic studies. Tree-Ring Bull 41:45-53

Environmental Defense Fund (1996) Available from http://rainbow.columbia.edu/edf/ info/dist/perm/ (cited 14 January 2005)

Fritts HC (1976) Tree rings and climate. Academic Press, London

Holmes RL (1983) Computer-assisted quality control in tree-ring dating and measurement. Tree-Ring Bull 43:69-78

Holmes RL (1994) Dendrochronology program library, version 1994. Laboratory of tree-ring research, University of Arizona, Tucson

Kagawa A, Sugimoto A, Maximov TC (2006) ${ }^{13} \mathrm{CO}_{2}$ pulse-labelling of photoassimilates reveals carbon allocation within and between tree rings. Plant Cell Environ 29 (doi: 10.11111/j. 1365-3040.2006.01533.x)

Kirchhefer AJ (2000) The influence of slope aspect on tree-ring growth of Pinus sylvestris L. in northern Norway and its implications for climate reconstruction. Dendrochronologia 18: 27-40

Kirdjanov AV, Zaharjevsky DV (1996) Dendroclimatological study on tree-ring width 
and maximum density chronologies from Picea obovata and Larix sibirica from the north of Krasnoyarsk region (Russia). Dendrochronologia 14: 227-236

Kirdyanov AV, Hughes MK, Vaganov EA, Schweingruber FH, Silkin P (2003) The importance of early summer temperature and date of snowmelt for tree growth in the Siberian subarctic. Trees 17: 61-69

Koike T, Mori S, Matsuura Y, Prokushkin SG, Zyranova OA, Kajimoto T, Abaimov AP (1998) Photosynthesis and foliar nutrient dynamics in larch and spruce grown on contrasting north- and south-facing slopes in the Tura Experiment Forest in Central Siberia. In: Mori S, Kanazawa Y, Matsuura Y, Inoue G (eds) Proceedings of the $6^{\text {th }}$ symposium on the joint Siberian permafrost studies between Japan and Russia in 1997. pp 3-10

Kujansuu J, Yasue K, Koike T, Abaimov AP, Kajimoto T, Takeda T, Tokumoto M, Matsuura Y Climatic responses of tree-ring widths of Larix gmelinii on contrasting north- and south-facing slopes in central Siberia. J Wood Sci (in press)

Monserud RA (1986) Time-series analyses of tree-ring chronologies. For Sci 32: 349-372

Naurzbaev MM, Vaganov EA (2000) Variation of early summer and annual temperature in east Taymir and Putoran (Siberia) over the last two millennia inferred from tree rings. J Geophys Res 105:7317-7326

Panyushkina IP, Hughes MK, Vaganov EA, Munro MAR (2003) Summer temperature in northeastern Siberia since 1642 reconstructed from tracheid dimensions and cell numbers of Larix cajanderi. Can J For Res 33: 1905-1914

Shcherbatjuk AS, Yan'kova LS, Rusakova LV (1990) Ecologo-physiological characteristics of gas exchange in conifers. Lesovedenie 4:3-10

Silkin PP, Kirdianov AV (2003) The relationship between variability of cell wall mass of earlywood and latewood tracheids in larch tree-rings, the rate of tree-ring growth and climatic changes. Holzforschung 57:1-7

Stewart RB, Wheaton E, Spittlehouse DL (1998) Climate change: implications for the boreal forest. In: Legge AH, Jones LL (eds) Emerging air issues for the 21st century: The need for multidisciplinary management, proceedings of a speciality conference, Sep 22-24, 1997, Calgary. SRC Publication, pp 86-101

Stokes MA, Smiley TL (1996) An introduction to tree-ring dating. University of 
Chicago Press, Chicago

Thomsen G (2001) Response to winter precipitation in ring-width chronologies of

Pinus sylvestris L. from the northwestern Siberian plain, Russia. Tree Ring Res 57(1):15-29

Vaganov EA, Hughes MK, Kirdyanov AV, Schweingruber FH, Silkin PP (1999) Influence of snowfall and melt timing on tree growth in subarctic Eurasia. Nature 400:149-151

Wigley TML, Briffa KR, Jones PD (1984) On the average value of correlated time series, with applications in dendroclimatology and hydrometeorology. J Clim App Meteo 23:201-213

Yasue K, Funada R, Kobayashi O, Ohtani J (2000) The effects of tracheid dimensions on variations in maximum density of Picea glehnii and relationships to climatic factors. Trees 14:223-229

Yasue K, Kujansuu J, Kajimato T, Nakai Y, Abaimov AP, Matsuura Y (2006) Seasonal changes in radial growth of Larix gmelinii in central Siberia in relation to its climatic responses. Abstracts of 7th International Conference on Dendrochronology. pp 147 


\section{Figure legends}

Fig. 1. Geographical location of the study sites ( $\boldsymbol{\square})$. The map shows the distribution of the permafrost in the Northern Hemisphere and the range of distribution of Larix species in Eurasia. The arrows in the small map show the direction of the river flow. Prepared from maps published by the Environmental Defense Fund (1996) and Abaimov et al. (1997).

Fig. 2. Schematic representation of the study sites. The depths of the active soil layers are indicated by numerical values and dotted lines, but are not shown to scale. The depths of the active soil layers at site one were recorded in the summer of 1997 (Koike et al. 1998), those at site two were recorded in autumn of 2003.

Fig. 3. Residual and standard chronologies of tree-ring widths of Larix gmelinii on the north- and south-facing slopes at sites one and two in Tura, central Siberia. Solid lines indicate residual chronologies and dotted lines indicate standard chronologies. The number of cores (solid) and trees (dotted) included per plot are indicated by the bottom lines.

Fig. 4. Residual and standard chronologies of maximum ring densities of Larix gmelinii on the north- and south-facing slopes at sites one and two in Tura, central Siberia. For further details see Fig. 3.

Fig. 5. Correlations between ring widths and ten-day average temperatures for Larix gmelinii on the north- and south-facing slopes at sites one and two in Tura, central Siberia. The thick lines and thin line indicate correlations of residual and standard chronologies, respectively. Each point represents the first day of the ten-day window with two-day lag. Horizontal lines indicate the levels at which correlations are significant $(p=0.05)$. Triangles and circles indicate significant correlations $(p<0.05)$ of residual and standard chronologies, respectively. Sinusoidal curves show mean values of ten-day average temperatures, as calculated for the period from 1930 to 1995. Letters of the alphabet indicate months of the year. 
Fig. 6. Correlations between ring widths and precipitation for Larix gmelinii on the north- and south-facing slopes at sites one and two in Tura, central Siberia. W, Winter (October to April) accumulation. Letters of the alphabet indicate months of the year. ME, MM and ML indicate early May, middle May and late May, respectively. For further details see Fig. 5.

Fig. 7. Variations in precipitation of winter and May from the Tura Meteorological Station (1939-1995), and standard chronologies of tree-ring widths for four plots in Tura, central Siberia. Thick lines are 5-year moving averages.

Fig. 8. Correlations between maximum densities and ten-day average temperatures for Larix gmelinii on the north- and south-facing slopes at sites one and two in Tura, central Siberia. For further details see Fig. 5.

Fig. 9. Correlations between maximum densities and precipitation for Larix gmelinii on the north- and south-facing slopes at sites one and two in Tura, central Siberia. For further details see Fig. 6. 
Fig. 1

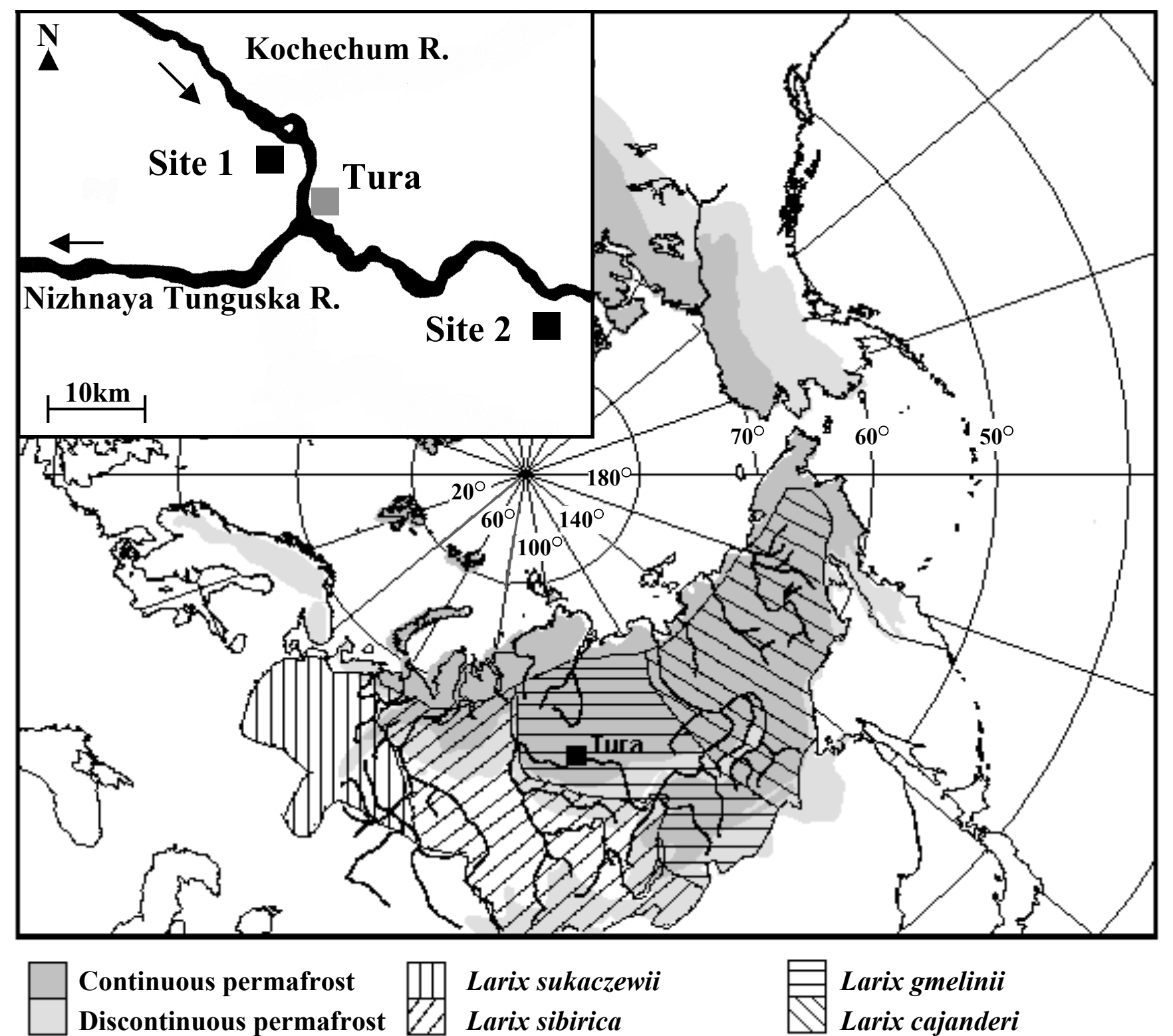




\section{Site 1}

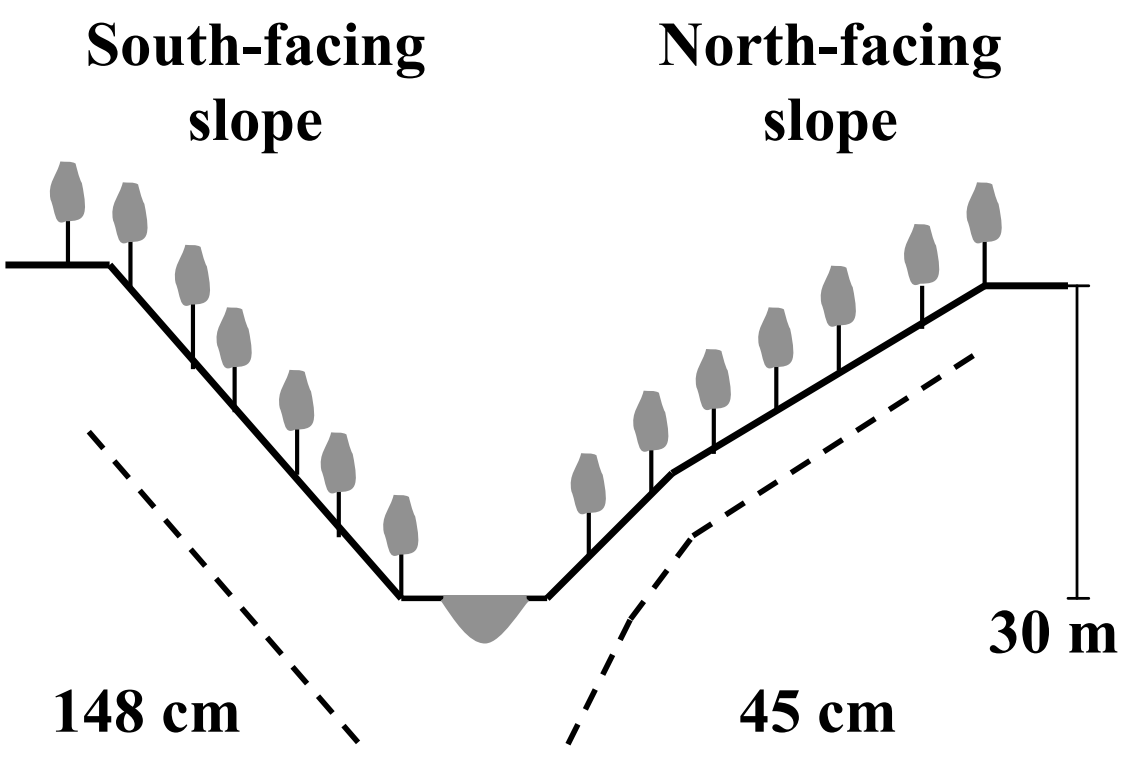

Site 2
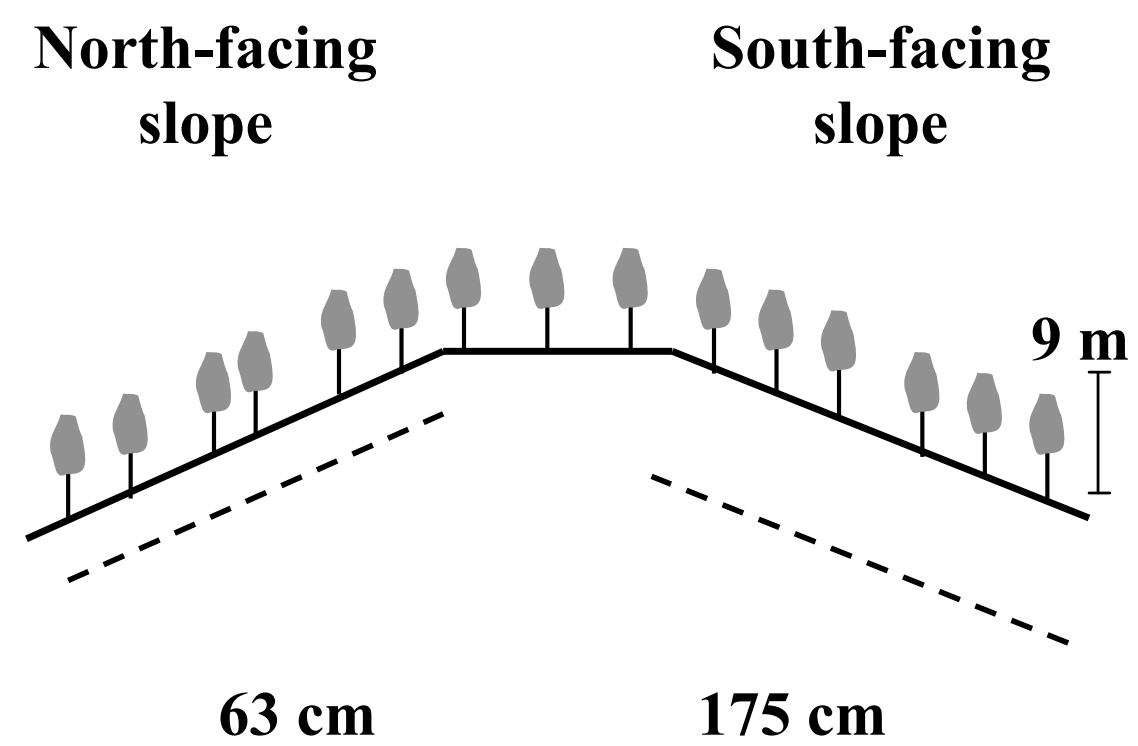
Fig. 3

Site 1
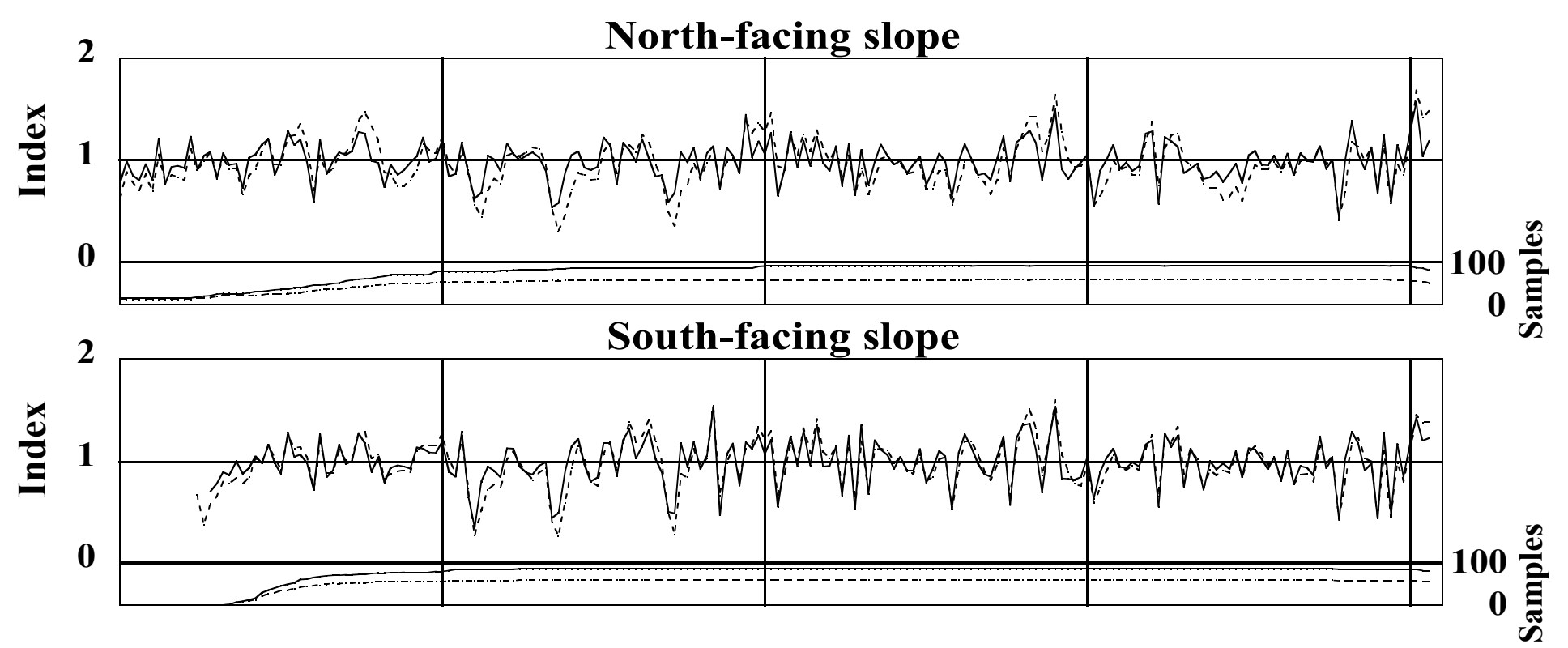

Site 2
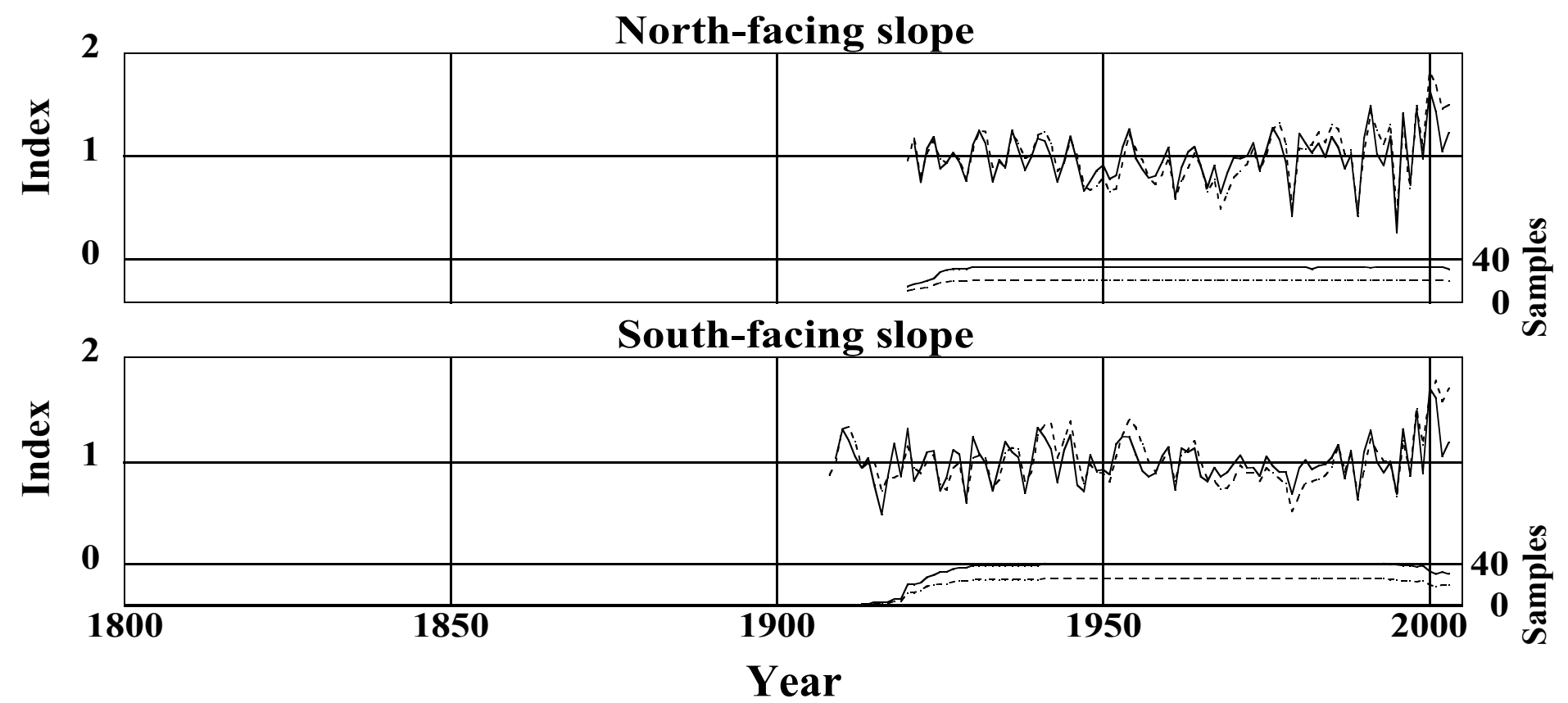
Fig. 4

Site 1
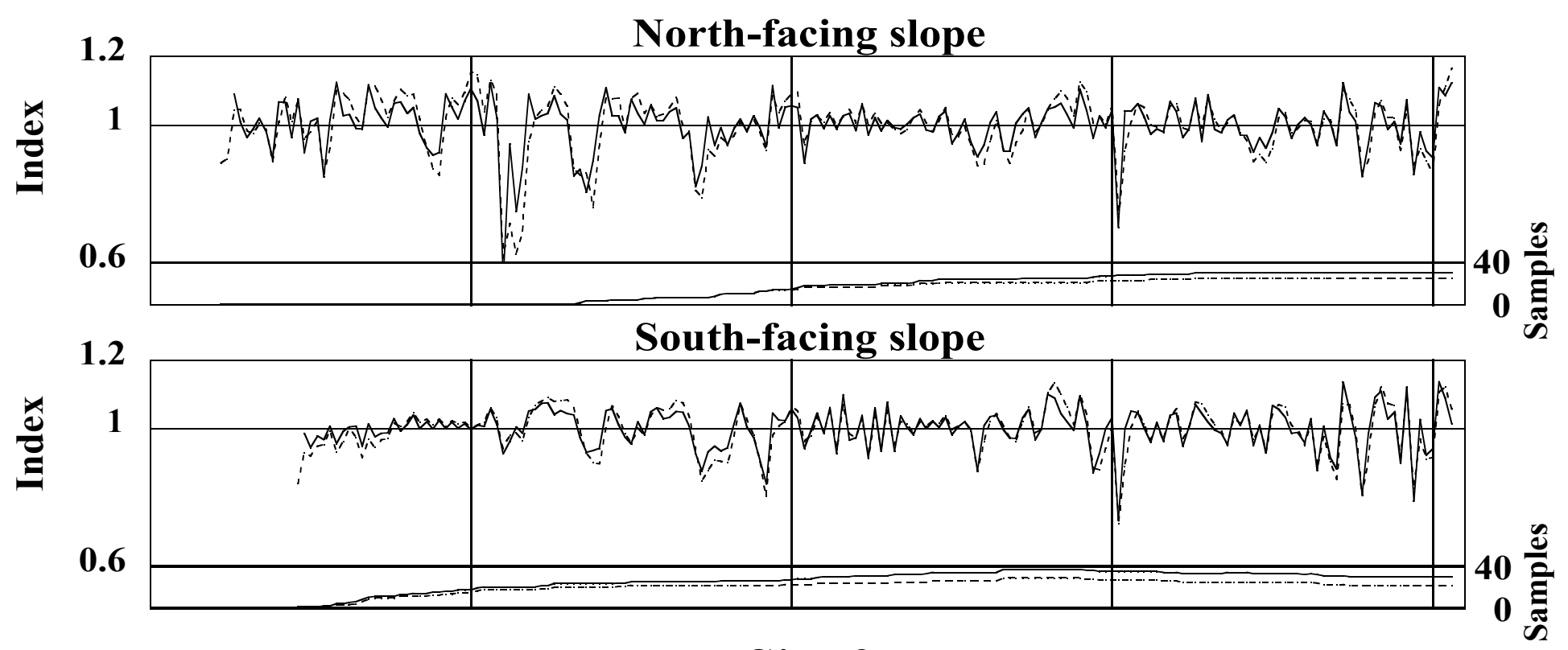

Site 2
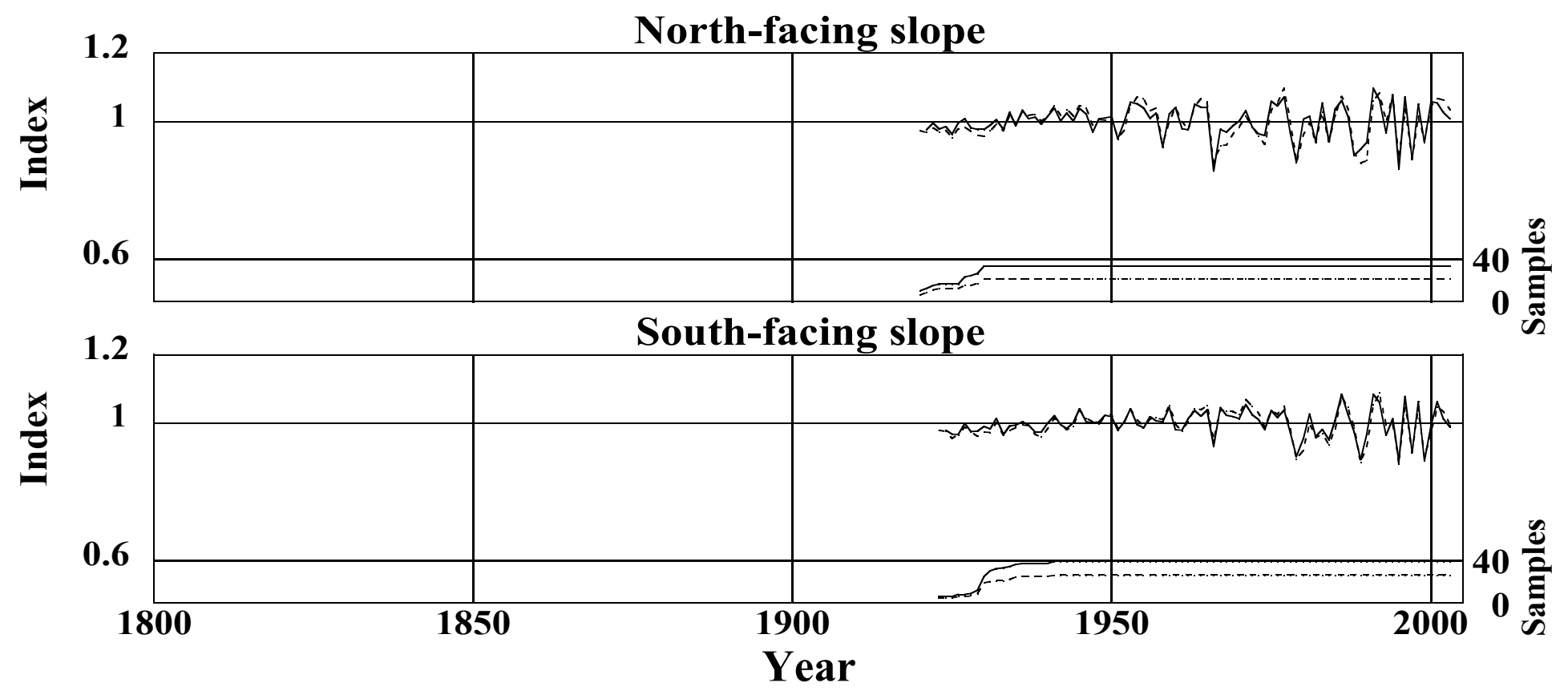


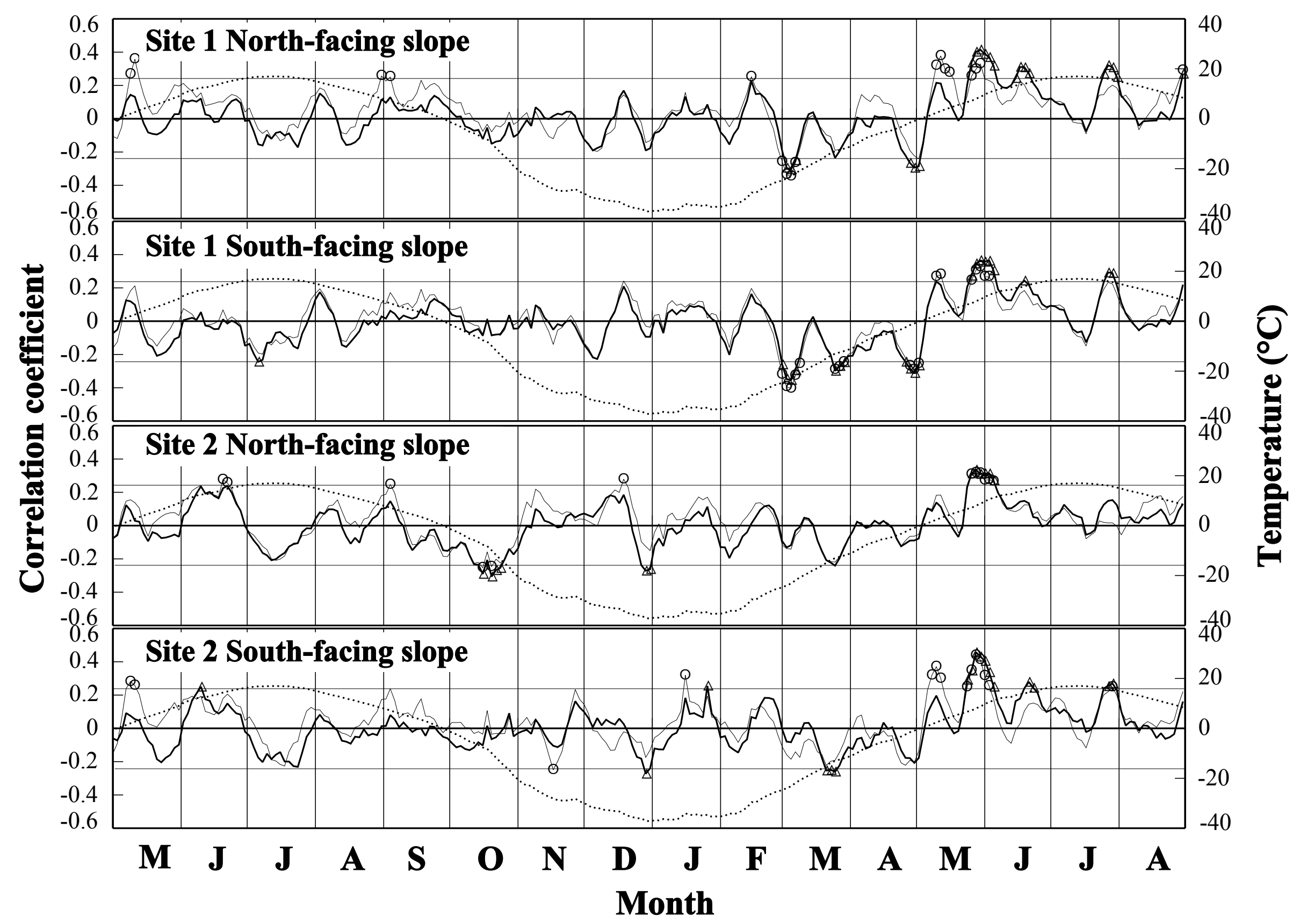




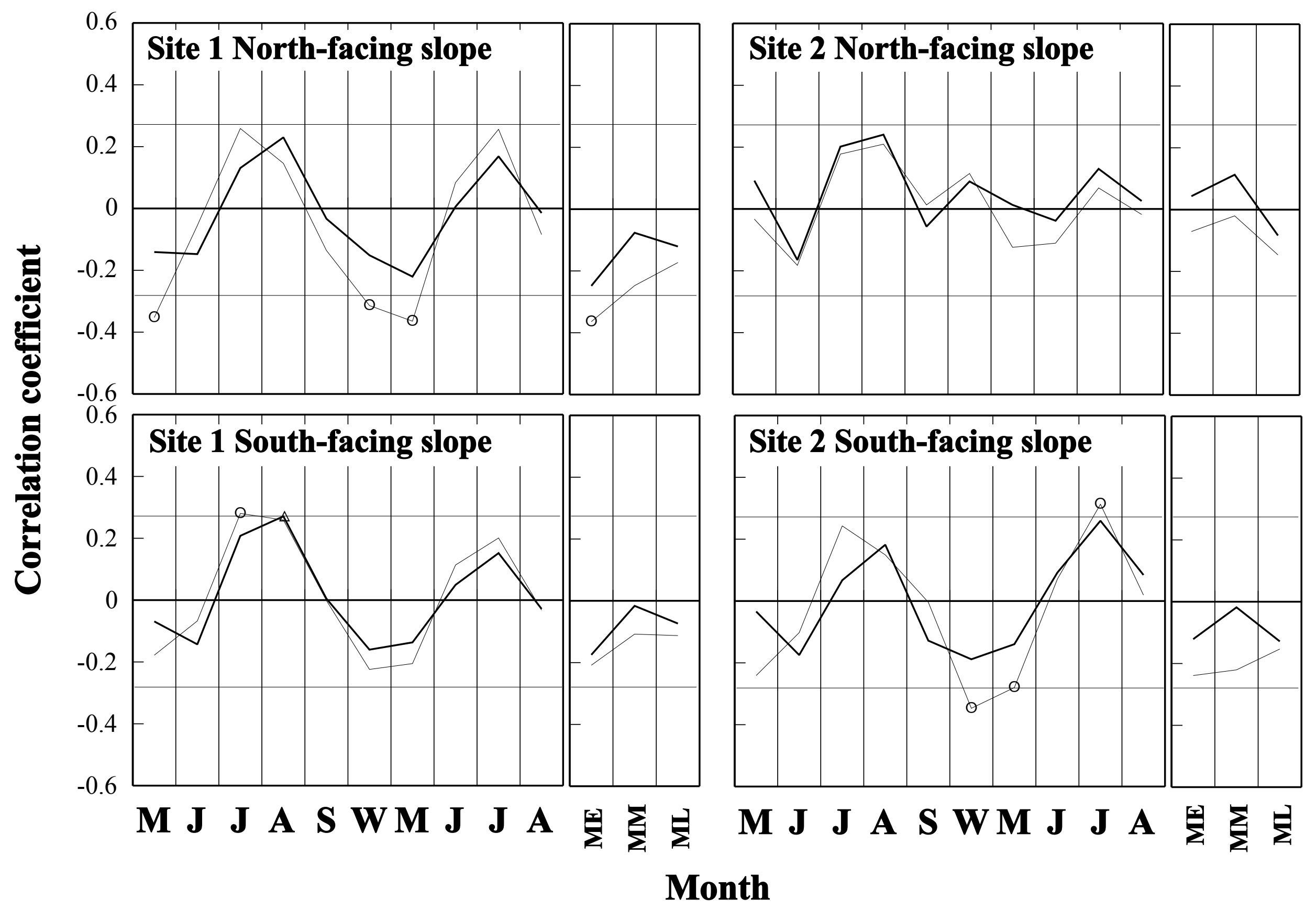


Fig. 7

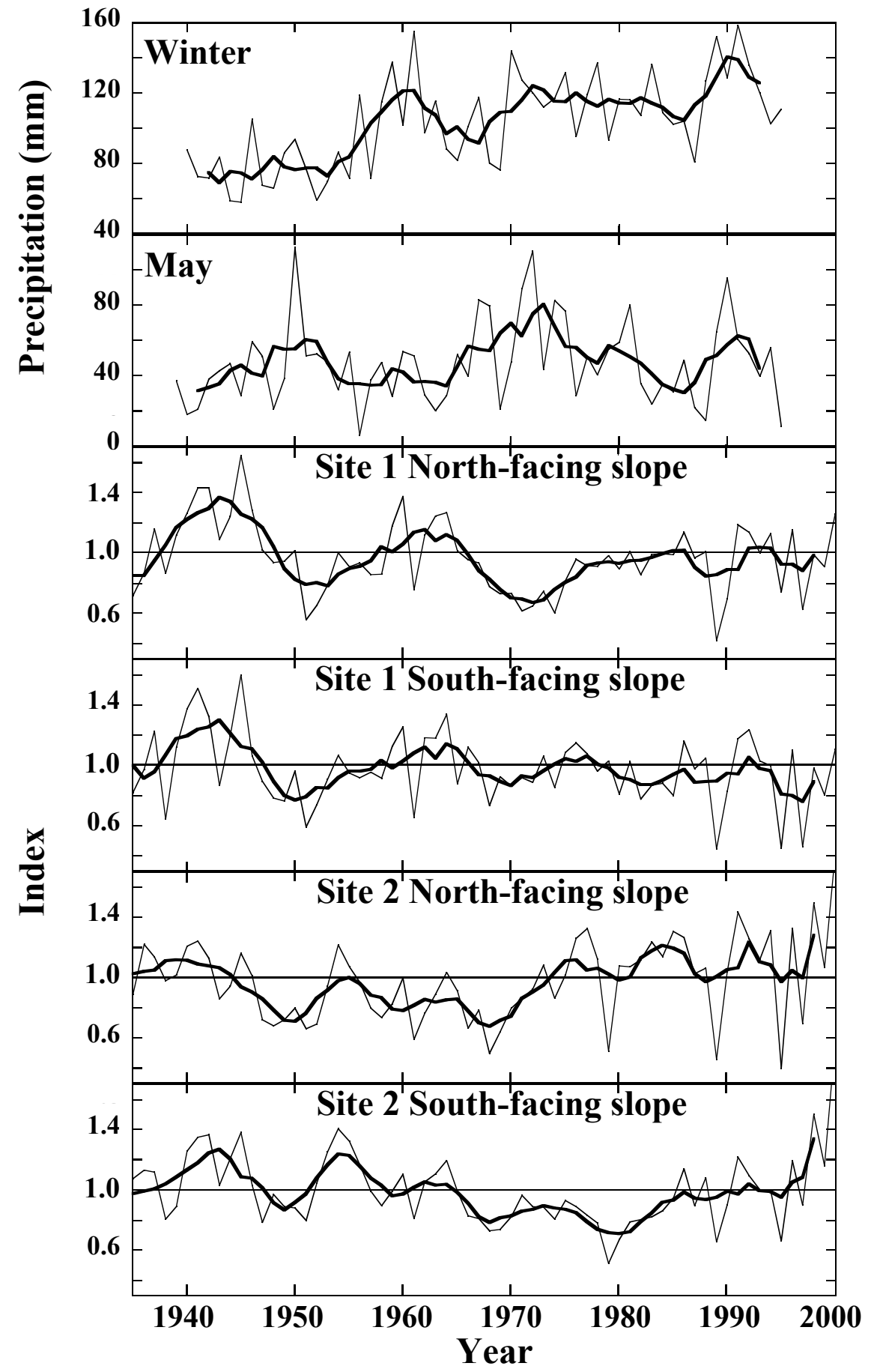




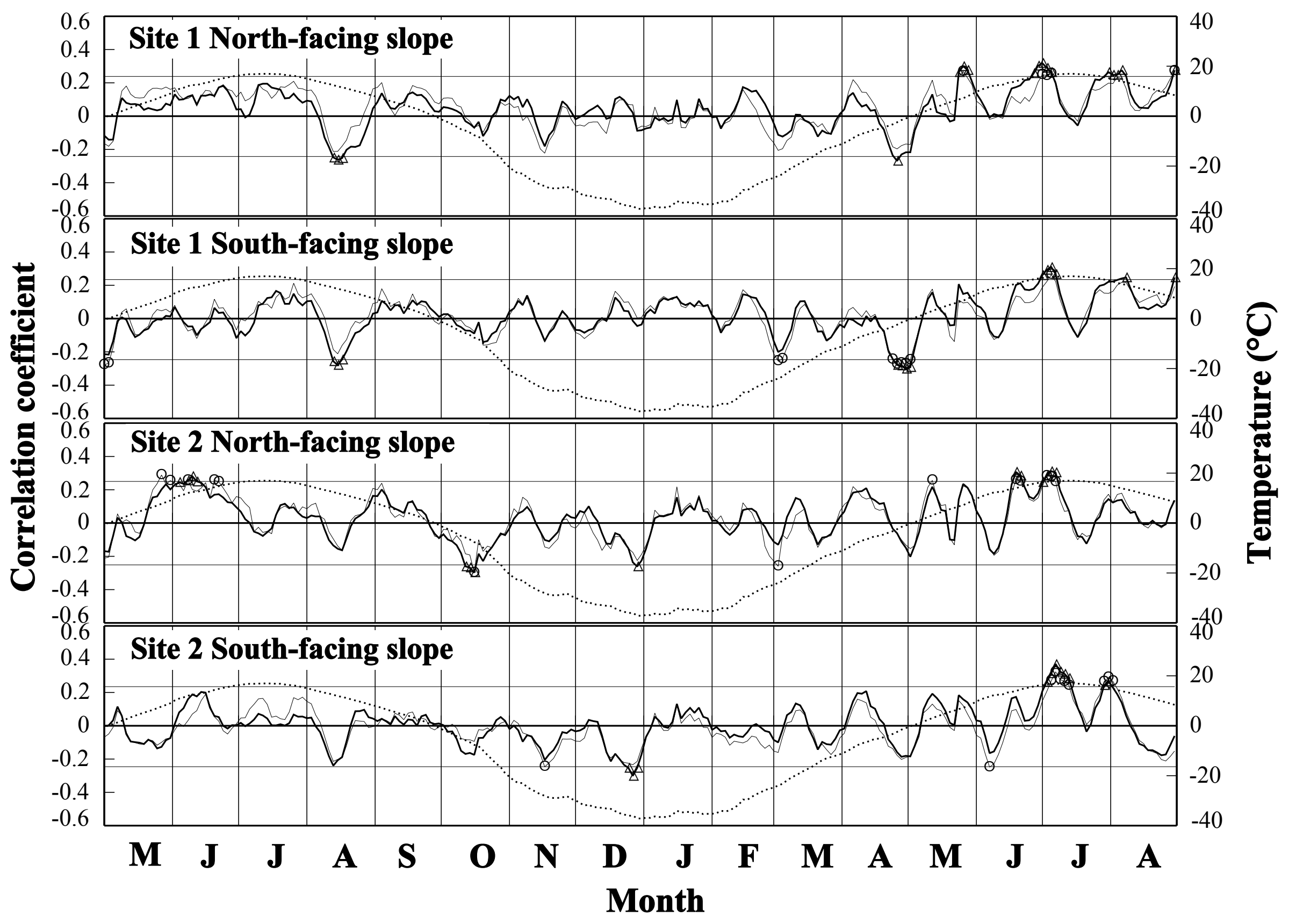




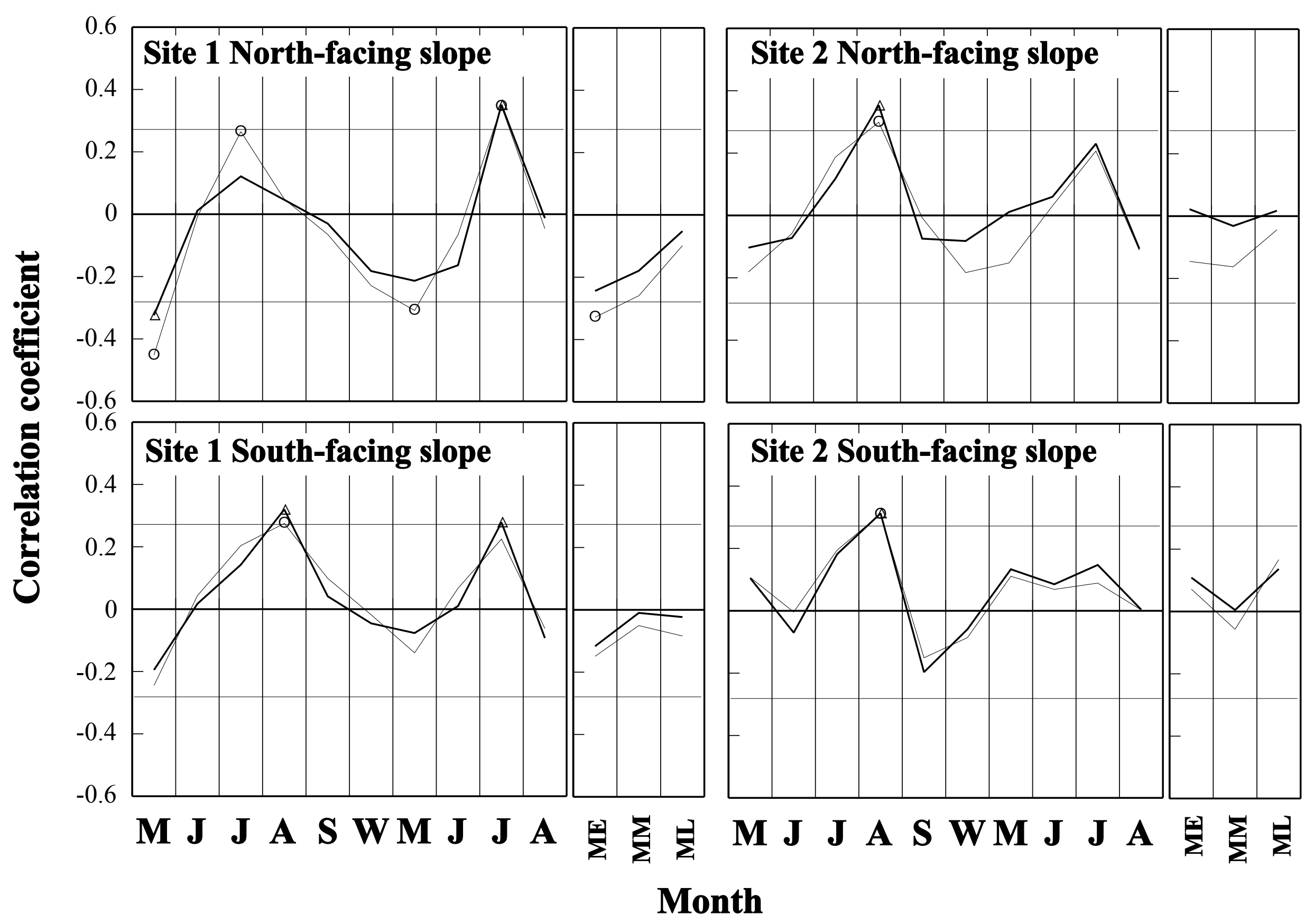

